\title{
New Energy Sources, Technologies, and Systems: The Priority of Social, Climate, and Environmental Issues
}

\author{
Jürgen-Friedrich Hake \\ Professor, j.f.hake@fz-juelich.de \\ Institute of Energy and Climate Research -IEK, Forschungszentrum Jülich, \\ Wilhelm-Johnen-Straße, 52428 Jülich, Germany
}

\section{Liliana Proskuryakova}

Director, National Contact Centre for International Academic Mobility, lproskuryakova@hse.ru

Institute for Statistical Studies and Economics of Knowledge at the National Research University Higher School of Economics (HSE ISSEK), 11 Myasnitskaya street, Moscow, 101000, Russian Federation

\begin{abstract}
$\mathrm{T}$ he introductory article to the special issue "The Future of Energy" is devoted to promising areas of development of the global energy complex, the assessment of their contribution to overcoming global challenges, and ensuring sustainable development. The trends under consideration differ significantly in the rate of evolution. Prospective
\end{abstract}

Abstract

\section{Keywords:}

new energy sources; technology evolution; global challenges; trends; sustainable development; state energy policy development trajectories present both opportunities and risks specific to the fuel and energy complex of particular countries. Success in using emerging advantages and leveling threats depends upon a combination of internal and external factors, including the choice of public policy measures and the effectiveness of their implementation.
Citation: Hake J.-F., Proskuryakova L. (2018) New Energy Sources, Technologies, and Systems: The Priority of Social, Climate, and Environmental Issues. Foresight and STI Governance, vol. 12, no 4, pp. 6-9. DOI: 10.17323/25002597.2018.4.6.9 
$\mathrm{T}$ he growing demand for energy in the context of social, climatic, and environmental constraints requires new energy sources. Among a multitude of factors that shape the future development of our energy systems are the volatility of energy prices, the ongoing and expected technological breakthroughs, and geopolitical shifts. These uncertainties compel decision-makers and researchers to look into the upcoming developments in an attempt to foresee and forecast such changes, master the trends, and take over new markets.

Among the technological areas being developed, thermonuclear fusion has the highest potential. Despite the delays and the high costs, the ITER remains the most promising nuclear fusion project; the results are expected in the medium to long term. The reactor's launch and operation will allow one to test the viability of the suggested engineering solutions and to assess economic feasibility of their commercialization. If the research turns out to be successful, ITER-based technological solutions may be implemented at nuclear fusion reactors [Rosanvallon et al., 2018]. The deployment of fourth-generation reactors is expected after 2030. The advantages of this approach include the development of a system comprising not only a reactor, but facilities for the disposal (recycling) of spent nuclear fuel, resulting in higher reliability and safety [Lake, 2002; Grape et al., 2014]. New multipurpose nuclear energy systems will generate heat and power. The main uncertainty factor here is the project costs affecting their competitiveness with other types of power generation. International cooperation and an interdisciplinary approach to energy research are among the most important success factors.

Before the invention of hydrogen fuel cells, the application of hydrogen for energy-related purposes was limited by low profit margins, high explosion hazards, and a lack of economically viable storage and distribution systems. Hydrogen fuel cells provided a solution for all these problems. Hydrogen has a very high energy density and is safe in mixtures with liquids, which makes its transportation possible via already existing liquid fossil fuel distribution networks. Also, hydrogen fuel cells allow for storing large volumes of electricity and make it available to users not connected to the grid. The possibility and time required to overcome the barriers hindering the large-scale application of hydrogen remain uncertain: insufficient safety and durability of fuel cells and hydrogen storage systems; the lack of a decentralized infrastructure that would make hydrogen cars attractive to consumers; and the high costs of electrolyzers and hydrogen production [Haseli, 2018].

The technology for the extraction of geothermal energy from hot dry rocks has been developed in Russia for decades: research and development projects have been completed and the systems have entered the demonstration phase. They are based upon technologies for the extraction and use of heat accumulated in the hot dry rocks of the earth's crust to generate affordable power and heat with stable adjustable parameters to provide a steady energy supply in remote and poorly developed regions of the country, as all those areas that have a power deficit. The existing solutions are fully based upon equipment that was produced in Russia and tested at Russian industrial enterprises. Research centers, universities, and industrial companies participated in the development of geothermal energy systems, the experimental version of which may be applied as early as 2016-2020, and large-scale industrial application is expected in 2020-2025 and onwards. This clean energy resource is attractive because of the low energy production costs, close to zero emissions, and an opportunity to recuperate excessive heat (through establishing a closed-cycle system) [Cui et al., 2017; Huang et al., 2018].

Researchers have been working on increasing the efficiency of solar energy use as early as in the 1940s, when it was suggested that an automated space station be launched to redirect solar energy to Earth using microwaves or laser beams [Asimov, 1967]. Today India, China, the United States, and Japan are developing their own satellite-based robotic solar power stations that would wirelessly transfer huge volumes of clean renewable energy to Earth. The main barrier hindering the construction of such stations is the high costs of space launches required to place the satellites into orbit. Accordingly, the first such space-based solar power plant is estimated to cost up to $\$ 20$ billion. Taking into account the declining space launch costs due to competition by private companies, this estimate may be revisited [Matsumoto, 2002; Potter, 2008].

Dark matter ${ }^{1}$ remains the least researched potential energy source. This work is currently at the basic research stage. Experiments to discover this matter are conducted at the LHC proton accelerator at the European Organization for Nuclear Research (Switzerland). The potential for using dark matter as an energy source for spacecraft on long missions is being discussed [ $\mathrm{Liu}, 2009]$. If relevant hypotheses are confirmed, a unit of dark matter mass could emit 5 billion times more energy than a mass unit of dynamite [Casalino et al., 2018].

The works published within the special issue of the Foresight and STI Governance "The Future of Energy" discuss in detail these and other aspects of energy technology development.

The article by Daniel and Jennifer Sklarew assesses the potential contribution of future energy systems to the achievement of sustainable development goals (SDGs) approved by the UN in 2015 [UN, 2015] that

\footnotetext{
According to one of the hypotheses, the visible mass of the Universe accounts for about $5 \%$ of common matter; $70 \%$ is "vacuum energy", and $25 \%$ is dark matter - matter that is invisible, does not emit either light or other electromagnetic waves and does not huddle when affected by gravity [Redd, 2017].
} 
address social concerns and security (resilience) issues [Schlör et al., 2018], affordability, environmental and climate friendliness, particularly by means of the combined use of water, energy, and agricultural resources [Märker et al., 2018]. Particularly, the $7^{\text {th }}$ SDG directly addresses global energy challenges: ensuring universal access to affordable, reliable, and modern energy services; substantially increasing the renewable energy share in the global energy mix; and doubling the global rate of improvement in energy efficiency. Multiple other SDGs are also directly and indirectly related to the most pressing energy issues around the globe [AIQattan et al., 2018]. Importantly, the SDGs go beyond the public good: they could be very relevant for businesses, in particular, through the application of various sustainability frameworks [Muff et al., 2017].

The requirements for energy changed dramatically with the onset of the next technological revolution. This process is discussed in detail in the article by Sergey Filippov. Foresight research of trends and technologies in the energy sector are carried out in many countries, particularly in North America, the European Union (EU), and the BRICS countries. Often, they are part of integrated systems of strategic planning at the national and international levels. The results obtained are taken into account in the development of science, technology, and innovation policy [Proskuryakova, 2017].

The foresight research methodology has made significant progress over the past ten years. The latest techniques are applied, including big data analysis using elements of artificial intelligence, advanced scenario planning, augmented by Delphi real-time surveys, and more [UNESCO, 2015; Miles et al., 2016]. This topic was developed in the article by Gilbert Ahamer, which is dedicated to the formation of a global change database (Global Change Data Base) and its application in Energy Foresight, while the prospects for the wider application of renewables in selected countries were analyzed by Nurcan Kilinc Ata.

One of the marked changes that already takes place is the increase in the number of market actors: former consumers have begun playing an active role in energy generation, storage, and trade [Zafar et al., 2018]. Citizens and enterprises are becoming prosumers and generate energy-related user innovations. Power-consuming and internet-connected home and industrial appliances and devices communicate with one another and power suppliers, thus regulating and optimizing their energy consumption without human intervention. The rapid growth of decentralized energy systems, smart grids of various sizes, and the Internet of Energy expansion are the trends that we witness today due to the aforementioned developments [Hong et al., 2018; Mahmud et al., 2018].

Another novelty that citizens in Tokyo, Berlin, Los Angeles, and in other metropolitan areas in Europe, America, and Asia note is the appearance of electric vehicle charging stations and hydrogen fueling stations [ICCT, 2017]. By 2020 the European Union aims to ensure that $10 \%$ of the transport fuel in every member country originates from renewable sources such as biofuels. The European producers already offer diesel with up to 7\% Fatty Acid Methyl Esters (FAME) (B7) and petrol with up to 5\% ethanol (E5). In 2015, the six EU member states with the largest ethanol content (10\%) in petrol were Bulgaria, Finland, France, Germany, Lithuania, and Slovenia [European Commission, 2017]. The leading producers of biofuel are the United States and Brazil [RFA, 2018]. Some countries, like Russia, have vast underexplored potential in biofuel production and exports [IRENA, 2017]. Inter-fuel competition on the Russian automobile market is assessed by Vyacheslav Kulagin et al.

Despite the available estimates of fossil fuels' undiscovered reserves, it is quite difficult to establish their actual volume. Some forecasts maintain that there is a substantial amount of hydrocarbons and no shortage should be expected in the foreseeable future. The opposite view has also been substantiated in the literature. Whatever the situation may be, estimates of the available reserves serve as an important parameter for planning the development of the energy industry [U.S. EIA, 2015]. Uncertainty regarding the total volume of undiscovered reserves is further increased by the unknown volume of commercially recoverable reserves. The production of unconventional and hard-to-extract hydrocarbons may turn out to be unprofitable. Technologies used for, and the energy intensity of, the extraction, beneficiation, and processing of fossil fuels may also vary greatly. All the above factors directly impact the energy balance. The prospects for unconventional oil extraction are analyzed in the article by Alexander Malanichev.

The rates of development of the considered global trends differ. Creating thermonuclear rectors may take decades, while new ways of extracting unconventional oil and gas reserves have already significantly transformed the global energy markets. As soon as the cost and energy technology problems that determine their competitiveness are solved, new developments can provide a breakthrough in various areas of applied research: from energy storage to new materials. Promising paths of development not only open up opportunities, but also pose threats specific to specific countries and their fuel and energy complexes. Success in catching up with the opportunities and combating the threats depends upon a combination of internal and external factors, including the selection of public policy measures and the formation of mechanisms for their effective implementation. 


\section{References}

AlQattan N., Acheampong M., Jaward FM, Ertem FC, Vijayakumar N., Bello T. (2018) Reviewing the numbers seven and eleven. Renewable Energy Focus, vol. 27, pp. 97-110.

Asimov I. (1967) Is Anyone There? Speculative Essays on the Known and Unknown, New York: Doubleday.

Casalino A., Rinaldi M., Sebastiani L., Vagnozzi S. (2018) Mimicking and GW170817. Physics of the Dark Universe, vol. 22, pp. 108-115.

Cui G., Rena S., Zhang L., Ezekiel J., Enechukwu C., Wang Y., Zhang R. (2017) . Energy, vol. 128, pp. 366-377.

The European Parliament (2017) Directive 98/70 / EC for the European Parliament and the Council of Europe ( COM (2017) 284 final). Brussels: European Commission. Available at: https://eur-lex.europa.eu/legal-content/EN/ TXT/?uri=CELEX\%3A52017DC0284, accessed 10/23/2018.

Grape S., Svärd SJ, Hellesen C., Jansson P., Lindell M.Å. (2014) New nuclear energy systems to support nuclear disarmament. Energy Policy, vol. 73, pp. 815-819.

Haseli Y. (2018) Maximum conversion efficiency of hydrogen fuel cells. International Journal of Hydrogen Energy, vol. 43, no 18, pp. 9015-9021.

Hong B., Zhang W., Zhou Y., Chen J., Xiang Y., Mu Y. ( 2018) Energy-Internet-oriented microgrid energy management system architecture and its application in China. Applied Energy, vol. 228, pp. 2153-2164.

Huang, W., Cao, W., Jiang, F. (2018) A geothermal energy exploitation. Energy, vol. 162, pp. 630-644.

ICCT (2017) Developing a cell phone for the transport of vehicles and vehicles for a vehicle that is a status update. Available at: https://www.theicct.org/sites/default/files/publications/Hydrogen-infrastructure-status-update_ ICCT-briefing_04102017_vF.pdf, accessed 10/25/2018.

IRENA (2017) Renewable Energy Prospects for the Russian Federation ( ReMap Working Paper), Abu Dhabi: IRENA.

Lake J.A. (2002) The fourth generation of nuclear power. Progress in Nuclear Energy, vol. 40, no 3 - 4 , pp . 301 - 307.

Liu J. (2009) Dark Matter as with the a the Possible the New Energy for the Source of Future Rocket Technology (ArXiv the Paper 0908.1429 [ astro - of ph . Co ]). Available at: https://arxiv.org/abs/0908.1429, accessed 09/19/2018.

Mahmud K., Town GE, Morsalin S., Hossain MJ (2018). Renewable and Sustainable Energy Reviews, vol. 82, part 3, pp. 4179-4203.

Märker C., SandraVenghaus S., Hake J.-F. (2018) IIntegrated governance for the food-energy-water nexus - The scope of action for institutional change. Renewable and Sustainable Energy Reviews, vol. 97, pp. 290-330.

Matsumoto H. (2002) Research on solar power satellites and Japan. IEEE Microwave Magazine, vol. 3, no 4, pp. 36-45.

Miles I., Saritas O., Sokolov A. (2016) Foresight for Science, Technology and Innovation, Heidelberg, New York, Dordrecht, London: Springer.

Muff K., Kapalka A., Dyllick T. (2017) The Gap Frame - Translating the SDGs into relevant national business challenges. The International Journal of Management Education, vol. 15, no 2, part 2, pp. 363-383.

Potter S., Henley M., Davis D., Born A., Howell J., Mankins J. (2008) Wireless Power Transmission Options for Space Solar Power. Paper Presented at NASA International Space Development Conference, Washington, DC, 29 May - 1 June 2008. Available at: https://ntrs.nasa.gov/archive/nasa/casi.ntrs.nasa.gov/20080036588.pdf, accessed 04/23/2018.

Proskuryakova L. (2017) Energy technology foresight in emerging economies. Technological Forecasting and Social Change, vol. 119, pp. 205-210.

Redd NT (2017) What is Dark Matter? Space.com, 14.11.2017. Available at : https://www.space.com/20930-darkmatter.html, accessed 12.04.2018.

RFA (2018) Renewable Fuels Association Database . Available at: https://ethanolrfa.org/resources/industry/ statistics/\#1454098996479-8715d404-e546, accessed 10/23/2018.

Rosanvallon S., Elbez-Uzan J., Cortes P. (2018) Safety Provisions for the ITER Facility. Fusion Engineering and Design, vol. 136, part A, pp. 540-544. Available at: https://doi.org/10.1016/j.fusengdes.2018.03.016, accessed 14.10.2018.

Schlör H., Venghaus S., Hake J.-F. (2018) The FEW-Nexus city index - Measuring urban resilience. Applied Energy, vol. 210, pp. 382-392. Available at: https://doi.org/10.1016/j.apenergy.2017.02.026, accessed 09.10.2018.

US EIA (2015) Annual Energy Outlook 2015 with projections to 2040, Washington DC: US Energy Information Administration.

UNESCO (2015) World Water Scenarios to 2050. World Water Assessment Program (WWAP), Paris: UNESCO.

UN (2015) Resolution adopted by the General Assembly on 25 September 2015, A / RES / 70/1, Geneva : United Nations. Available at: http://www.un.org/ga/search/view_doc.asp?symbol=A/RES/70/1\&Lang=E, accessed 10/23/2018.

Zafar R., Mahmood A., Razzaq S., Ali W., Naeema U., Shehzada K. (2018) Prosumer based energy management and smart grid. Renewable and Sustainable Energy Reviews, vol. 82, part 1, pp. 1675-1684. 